\title{
Profitability of no-till grain production systems
}

\section{Rentabilidade de sistemas de produção de grãos sob plantio direto}

\author{
Rafael Fuentes-Llanillo ${ }^{1 *}$; Tiago Santos Telles ${ }^{1}$; Bruno Volsi²; \\ Dimas Soares Júnior ${ }^{1}$; Sergio Luiz Carneiro ${ }^{3}$; Maria de Fátima Guimarães ${ }^{4}$
}

\begin{abstract}
In general, the technical and agronomic benefits of no-till farming are widely known and well documented in the literature. However, studies focusing on the economics of no-tillage are scarce. In this context, the objective of this study is to determine whether no-till grain production systems that follow the principles of conservation agriculture are economically profitable by analyzing gross margins per hectare per year over six harvests for the agricultural years 1998/1999 to 2003/2004. In addition, a possible link between profitability and different no-till methods in terms of degree of soil turnover, crop rotation, and whether machinery used in agricultural operations is owned or rented is investigated. For this purpose, the multi-case analytical method was applied to thirteen grain producing family farms in Northern Paraná state, Brazil. Based on the results, two ranges of agricultural production variable costs and gross margins were identified. Higher gross margins were associated with longer use of the no-till system, ownership of machinery and equipment, specialization in grains, rotation of the commercial crops used, and higher variable costs. Lower gross margins were associated with outsourcing of sowing, small-scale cropping, and lack of crop rotation. It is concluded that family mechanized no-till systems of grain production in north Paraná are profitable.
\end{abstract}

Key words: Economic analysis. Gross margin. No-till system. Conservation agriculture. Family farming.

\section{Resumo}

Em geral, os benefícios técnico-agronômicos do plantio direto são amplamente conhecidos e encontramse bem documentados na literatura, entretanto, estudos voltados aos aspectos econômicos do plantio direto são escassos. Nesse contexto, o objetivo deste estudo foi avaliar a rentabilidade de lavouras de grãos, sob plantio direto, por meio da análise das margens brutas por hectare ao ano, ao longo de seis safras, considerando os anos agrícolas de 1998/1999 a 2003/2004. Além disso, foi averiguada se há uma relação entre a rentabilidade e os diferentes tipos de plantio direto, no que diz respeito ao grau de revolvimento do solo, à realização de rotação de culturas e se o maquinário para a realização das operações agrícolas era próprio ou alugado. Para tanto, utilizou-se a metodologia de análise multicaso, considerando treze estabelecimentos agrícolas familiares, produtores de grãos, do Norte do Paraná, Brasil. Com base nos resultados foram identificados duas faixas de custos variáveis e de margens brutas da produção agrícola. Maiores margens brutas estiveram associadas ao maior tempo de utilização do sistema plantio direto, à posse de maquinário e equipamentos próprios, à especialização em grãos, à rotação de culturas comerciais utilizadas e aos maiores custos variáveis. Menores margens brutas

\footnotetext{
${ }^{1}$ Pesquisadores, Área de Socioeconomia, Instituto Agronômico do Paraná, IAPAR, Londrina, PR, Brasil. E-mail: rfuentes@iapar. br; telles@iapar.br; dimasjr@iapar.br

2 Discente de Mestrado, Programa de Pós-Graduação em Agronomia, Universidade Estadual de Londrina, UEL, Londrina, PR, Brasil. E-mail: bruno_volsi@hotmail.com

${ }^{3}$ Eng $^{\circ}$ Agr $^{\circ}$, Instituto Paranaense de Assistência Técnica e Extensão Rural, EMATER, Londrina, PR, Brasil. E-mail: sergiocarneiro@ emater.pr.gov.br

${ }^{4}$ Prof ${ }^{\mathrm{a}}$ Titular, Departamento de Agronomia, UEL, Londrina, PR, Brasil. E-mail: mfatima@uel.br

* Author for correspondence
} 
estiveram associadas ao uso de terceirização na semeadura, à pequena escala das lavouras e à falta de rotação de culturas. Conclui-se que sistemas familiares de produção mecanizada de grãos, em plantio direto, no norte do Paraná são rentáveis.

Palavras-chave: Análise econômica. Margem bruta. Sistema Plantio Direto. Agricultura conservacionista. Agricultura familiar.

\section{Introduction}

The search for sustainable agricultural systems is a challenge, post green-revolution, for all of Brazilian society. An alternative in the pursuit of sustainability has been the expansion of no-till (NT) farming and of the no-tillage system (NTS) within the framework of conservation agriculture (KASSAM et al., 2009; LAL, 2007). NT is defined as the planting of crops directly in the soil without any prior primary or secondary soil preparation, with only a narrow strip opened deep enough to deposit seeds and fertilizers (BOLLIGER et al., 2006; CHRISTOFFOLETI et al., 2007). In turn, the notillage system (NTS) is based on three fundamental principles: no soil turnover, permanent soil cover, and crop rotation (HOBBS et al., 2008). However, this concept has been expanded into what is called quality NTS, where soil conservation management techniques are used to their full extent: crop rotation, cover crops, appropriate seeders, and extensive soil fertility management (physical, chemical and biological) and rationalization of chemical inputs to reduce production costs and environmental contamination (CASÃO JÚNIOR et al., 2006).

In general, the biophysical benefits of NT are widely known and well documented in the literature. Its use has been shown to result in improved physical soil conditions (BLAINSKI et al., 2012; ROSIM et al., 2012); superior biological indicators (CARNEIRO et al., 2009; SAPKOTA et al., 2012; SILVA et al., 2007); increased organic matter levels (WINCK et al., 2014; SÁ; LAL, 2009); greater soil and water conservation (ALMEIDA et al., 2016; MENDES; TOURDONNET, 2013; OLIVEIRA et al., 2012); a reduced number of agricultural operations; a reduction in labor requirements (LIBARDI; DELGADO, 1999); and decreased use of machinery and fuel consumption (FERNANDES et al., 2008; CORTEZ et al., 2009). However, studies focused on the economic aspects of NT are scarce (OLIVEIRA et al., 2013; EL-SHATER et al., 2016).

Paraná is the Brazilian state with the highest relative share of NT in its territory, corresponding to $73.7 \%$ of the entire area covered by annual crops (FUENTES-LLANILLO et al., 2013). However, in the same region, the level of yields and profitability of each farm depends on several factors, such as edaphoclimatic factors, the rotation or succession of crops, or even the type of farm management employed (URI, 1999). Given the widespread use of NT, there is no doubt that it is profitable (SILVA et al., 2009). However, the fact is that there are several ways of employing it (SCOPEL et al., 2013), resulting in different quality levels, degrees of sustainability and economic profitability. The challenge is to describe the production systems adopted by the rural producers and identify which ones are most profitable, highlighting the adaptations made relative to established techniques.

Thus, it is hypothesized that producers who adopt production systems aligned with the precepts of conservation agriculture and quality NTS are more profitable than those who neglect them.

In this context, the objective of this study is to determine whether no-till grain production systems that follow the precepts of conservation agriculture are economically profitable. 


\section{Materials and Methods}

The research utilized the methodology of a quantitative and qualitative multicase ${ }^{5}$ study. The focus of the study was thirteen farms participating in the "Reference Networks (Redes de Referência)" project, developed jointly by the Agronomic Institute of Paraná State (IAPAR) and the Paraná Institute of Technical Assistance and Rural Outreach (EMATER-PR) in the administrative regions of Londrina, Apucarana and Cornélio Procópio in the state of Paraná.

The selected agricultural producers, representative of the production systems adopted in the region, were from grain-producing farms that used or started using NT in the period from $1998 / 1999$ to $2003 / 2004$. Technical-economic information regarding these production units was collected for the agricultural years, 1998/1999 through 2003/2004. In addition, interviews were conducted on soil management modalities and the typology of NT or NTS applied in the production units.

The production systems under NT analyzed in this study were classified from I to XIII (Table 1). Among the establishments, seven developed specialized production, and six developed diversified production.

Table 1. Grain production systems under no-tillage in family farms in Northern Paraná state, used in the agricultural years of 1998/1999 to 2003/2004.

\begin{tabular}{cccc}
\hline Farm & Production system & Type of No-Tillage in 2004 & Year of adoption ${ }^{(1)}$ \\
\hline I & Specialized & No-tillage with crop rotation & 1995 \\
II & Specialized & No-tillage with crop rotation & 1994 \\
III & Specialized & No-tillage with crop rotation & 1995 \\
IV & Specialized & No-tillage with crop rotation & 1997 \\
V & Specialized & No-tillage with incipient crop rotation & 1994 \\
VI & Specialized & No-tillage without crop rotation ${ }^{(2)}$ & 1995 \\
VII & Specialized & Minimal preparation with incipient crop rotation & 1997 \\
VIII & Diversified & No-tillage without crop rotation & 2000 \\
IX & Diversified & No-tillage without crop rotation & 1999 \\
X & Diversified & No-tillage without crop rotation & 1998 \\
XI & Diversified & No-tillage without crop rotation & 2002 \\
XII & Diversified & No-tillage without crop rotation & 2000 \\
XIII & Diversified & Conventional tillage ${ }^{(3)}$ without crop rotation & 1997 \\
\hline
\end{tabular}

${ }^{(1)}$ Year of no-tillage adoption. ${ }^{(2)}$ In 2002, performed soil scarification. ${ }^{(3)}$ In 2004, performed soil scarification in summer and used a disc harrow in winter.

Study site

The 13 farms studied are located in eight municipalities in the Paranapanema Valley in the state of Paraná, between $50^{\circ} 10^{\prime}$ and $51^{\circ} 30^{\prime} \mathrm{W}$ and

\footnotetext{
5 A multicase study is an empirical analysis used to investigate a phenomenon within the context in which it occurs, based on multiple sources of evidence and without generalizing the results to the entire population. As it is a type analysis appropriate to the identification of common and uncommon factors within the same group, the muticase study allows for an increasingly detailed investigation, making it possible to identify new elements that add value to previous findings.
}

$22^{\circ} 40^{\prime}$ and $23^{\circ} 30^{\prime} \mathrm{N}$ (between the Paranapanema River and the Tropic of Capricorn). The hub city is Londrina. The altitude varies between $350 \mathrm{~m}$ and $700 \mathrm{~m}$ above sea level, and the predominant soil type in the plots studied is Red Latosol, according to the Brazilian classification (SANTOS et al., 2006), or Typic Haplorthox, according to FAO classification, with clay content varying from $55 \%$ to $70 \%$. The mean rainfall in the region ranges from $1,350 \mathrm{~mm}$ to $1,650 \mathrm{~mm}$ annually, with significant interannual variation. 


\section{Economic analysis}

For each of the 13 farms, technical and economic data were compiled, and variable costs (VC), gross income (GI), and gross margin (GM) per hectare of useful agricultural area (UAA) were calculated for the period from 1998/1999 to 2003/2004, according to the following equations:

$V C=$ inputs + fuel and maintenance $+O L+M R \quad 1$

where VC is variable costs, OL is outsourced labor, and MR is the machinery rental. In this study, fixed costs or opportunity costs (income foregone) are not considered.

$$
G I=Q \cdot P
$$

where GI is gross income, Q is the quantity of grain produced, and $\mathrm{P}$ is the grain price received by producers.

$$
G M=G I-V C
$$

where GM is the gross margin, GI is gross income, and $\mathrm{VC}$ are variable costs.

$$
\frac{G M}{U A A}=\frac{G I}{S A U}-\frac{C V}{S A U}
$$

where GM is the gross margin, UAA is the agricultural area in hectares used in the cultivation of grains on each farm, GI is gross income, and VC is variable costs.

All grain prices were reported by the producers themselves. All monetary values are presented in real terms, based on the Broad Consumer Price Index (Índice Nacional de Preços ao Consumidor Amplo - IPCA), with July 2016 as the base period.

It should be noted that gross margin is one of the most frequently used indicators in analyses of the economic sustainability of farms (FURLANETO; ESPERANCINI, 2010; OLIVEIRA et al., 2009; SABUNDJIAN et al., 2014). This is mainly due to the ease of obtaining it and the practical significance of knowing how much total income is left after direct expenses are subtracted. The weighted gross margin per unit area also allows comparison between farms and treatments (KHATOUNIAN; SOARES JÚNIOR, 2005; LEAL et al., 2005; MIRANDA et al., 2009). The variations in the dollar exchange rate and the international commodities market raised the real price of a bag of soybeans $(60 \mathrm{~kg})$ relative to 2001 by $13.23 \%$ in $2002,66.16 \%$ in 2003 , and $18.95 \%$ in 2004 and are therefore responsible for a significant increase in the gross income and gross margin of producers in the last three years of the analysis, a period that can thus be characterized as extremely favorable to farmers. Wheat and corn prices also had a positive impact on producer incomes in 2002 and 2003.

Interview on soil management modalities and notill farming

With the possession of technical-economic data over six years, a semi-structured interview was conducted in December 2005, highlighting the following themes: soil management, no-till land use, seeding machines, harvesters, agricultural operations, machine traffic, and no-tillage and conventional tillage classification types. The interview method adopted followed Miranda et al. (2009).

\section{Statistical analysis}

The Scott-Knott grouping test $(p<0.01)$ was performed to determine differences between treatments in relation to both variable costs (VC) and gross margin (GM). The analyses were performed using SAS 9.1.

\section{Results and Discussion}

Tables 1 and 2 were generated from the analysis of average gross margins per hectare and the information collected in the interviews describing the types of no-tillage soil management identified. There are four main categories of no-tillage soil 
management: no-tillage in the medium term (NT$\mathrm{MT}$ ), with and without crop rotation; direct seeding on straw in the medium term (MPDS-MT), with minimal preparation and without crop rotation; no-tillage in the short term (NT-ST), without crop rotation; and conventional tillage in the medium term (CT-MT), without crop rotation, where the latter has recently included no-till.

Table 2. Grain production systems under no-tillage in family farms in Northern Paraná state, from 1998/1999 to $2003 / 2004$.

\begin{tabular}{|c|c|c|c|c|c|c|c|c|c|c|c|c|c|}
\hline \multirow{3}{*}{ Farm } & \multicolumn{6}{|c|}{ Rotation } & \multicolumn{7}{|c|}{ Machinery profile } \\
\hline & \multicolumn{3}{|c|}{ Summer } & \multicolumn{3}{|c|}{ Winter } & \multicolumn{3}{|c|}{ Planter } & \multicolumn{2}{|c|}{ Seeder } & \multicolumn{2}{|c|}{ Harvester } \\
\hline & $\mathrm{S}$ & $\mathrm{C}$ & W & OSC & WO & $\mathrm{BO}$ & TR & $\mathrm{O}$ & $\mathrm{R}$ & $\mathrm{O}$ & $\mathrm{R}$ & $\mathrm{O}$ & $\mathrm{R}$ \\
\hline I & $\mathrm{X}$ & $\mathrm{X}$ & $\mathrm{X}$ & $\mathrm{X}$ & - & - & - & $\mathrm{X}$ & - & $\mathrm{X}$ & - & - & $\mathrm{X}$ \\
\hline II & $\mathrm{X}$ & $X$ & $X$ & $\mathrm{X}$ & $\mathrm{X}$ & $\mathrm{X}$ & $\mathrm{X}$ & $X$ & - & $\mathrm{X}$ & - & $\mathrm{X}$ & - \\
\hline III & $\mathrm{X}$ & $\mathrm{X}$ & $\mathrm{X}$ & $\mathrm{X}$ & - & & $\mathrm{X}$ & $\mathrm{X}$ & - & $\mathrm{X}$ & - & $\mathrm{X}$ & - \\
\hline IV & $X$ & $X$ & $X$ & - & - & $X$ & - & $X$ & - & $\mathrm{X}$ & - & $\mathrm{X}$ & - \\
\hline V & $X$ & $X$ & $X$ & - & - & - & - & - & $\mathrm{X}$ & $\mathrm{X}$ & - & - & $X$ \\
\hline VI & $X$ & - & - & $\mathrm{X}$ & - & - & - & $X$ & - & - & $X$ & - & $\mathrm{X}$ \\
\hline VII & $X$ & - & $X$ & $\mathrm{X}$ & - & - & - & $\mathrm{X}$ & - & $\mathrm{X}$ & - & - & $\mathrm{X}$ \\
\hline VIII & $X$ & - & $X$ & - & - & - & - & $X$ & - & $\mathrm{X}$ & - & - & $\mathrm{X}$ \\
\hline IX & $X$ & - & $X$ & - & - & - & - & $X$ & - & $\mathrm{X}$ & - & $X$ & - \\
\hline$X$ & $\mathrm{X}$ & $X$ & $X$ & - & - & - & - & - & $\mathrm{X}$ & - & $\mathrm{X}$ & - & $X$ \\
\hline XI & $X$ & - & $X$ & - & - & - & - & - & $\mathrm{X}$ & - & $\mathrm{X}$ & - & $\mathrm{X}$ \\
\hline XII & $\mathrm{X}$ & - & - & $\mathrm{X}$ & - & - & - & - & $\mathrm{X}$ & - & $\mathrm{X}$ & - & $X$ \\
\hline XIII & $\mathrm{X}$ & - & $X$ & - & - & - & - & - & $X$ & - & $\mathrm{X}$ & - & $\mathrm{X}$ \\
\hline
\end{tabular}

S: soybean. C: corn. W: wheat. OSC: off-season corn. WO: white oat. BO: black oat. TR: triticale. O: owned. R: rented.

At six farms (I to VI), NT-MT was applied. All were specialized in grain ${ }^{6}$ cultivation, with planting areas varying from 38 ha to 48 ha. On four of these farms, crop rotations were performed; on the other two, crop rotation was incipient ${ }^{7}$ or not performed. Crop rotation is relatively simple and includes corn in the summer in the soybean/wheat succession, often followed by off-season corn as a soil cover recovery strategy. Black oat, triticale, and white oat are also used in winter rotations but are always used for grain production or animal feed. In the period of analysis, there was no case of exclusive use of crops as green manure or cover crop. Only farm V rented a planter.

\footnotetext{
${ }_{6}$ This assumes as a specialization criterion the condition that more than $70 \%$ of total gross income of the establishment is derived from the activities in question.

7 With little species diversification, with rotation performed only in the winter.
}

On farm VII, also specialized in grains, with an area of 53 ha, MPDS-MT was performed, with incipient rotation of soybeans with wheat and/or offseason corn. The minimum preparation consisted of scarification and direct seeding of soybean and light harrowing and direct sowing of wheat or offseason corn. Following wheat, no-till soybean was started in 2002/03. Scarification was performed on off-season corn.

On five farms (VIII to XII), NT-ST was carried out, with grain areas varying from 10 ha to 28 ha, without crop rotation, four with soybean/wheat succession, and one with soybean/off-season corn succession. All farms in this group were diversified, combining grain income with other activities, such as coffee, banana, peach, and orange cultivation and broiler chicken raising. In this group, two producers owned their own planters and seeders, while three others rented the equipment. 
Finally, on farm XIII, in which no-tillage was adopted only in the final period of analysis (20032004), CT-MT was performed in 2002-2003, using scarification in the summer and heavy harrowing in the winter, with 16 ha of soybean/wheat without crop rotation, diversified with coffee.

With regard to profitability, the effects of adoption of no-tillage exceeded those of conventional tillage, mainly due to a reduction in variable costs and increases in grain yields. The most significant cost reduction arises from the elimination of soil preparation operations and can vary substantially between regions, depending on the time of adoption (short term versus long term) and fuel prices. Another advantage of the system in the long term is the reduced need for chemical fertilizers, which represent $20 \%$ to $30 \%$ of variable production costs (CASTRO et al., 2006; CAVALETT; ORTEGA, 2009).

In Table 3, through the grouping test $(p<0.01)$, the data are classified into two gross margin ranges: one higher, ranging in American Dollars (US\$) from US\$ 913.55 to US\$ 1,244.21 per hectare per year; and one lower, ranging from US\$ 443.96 to US\$ 631.68 per hectare per year. With regard to variable costs, two ranges were also defined: one with higher costs, ranging from US\$ 704.85 to US\$ 883.30 per hectare per year; and another with lower costs, ranging from US\$ 459.71 to US\$ 632.91 per hectare per year.

Table 3. Area, mean yields, variable cost and gross margin of no-till grain production systems in family farms in Northern Paraná state, from 1998/1999 to 2003/2004.

\begin{tabular}{|c|c|c|c|c|c|c|c|c|c|c|c|}
\hline \multirow[t]{2}{*}{ Farm } & \multirow[t]{2}{*}{$\begin{array}{c}\operatorname{Area}^{(1)} \\
\text { (ha) }\end{array}$} & \multicolumn{3}{|c|}{ Observed harvest } & \multicolumn{5}{|c|}{$\begin{array}{l}\text { Mean yields } \\
\left(\mathrm{kg} \mathrm{ha}^{-1}\right)\end{array}$} & \multirow{2}{*}{$\begin{array}{c}\begin{array}{c}\text { Variable } \\
\text { cost }^{(3)}\end{array} \\
\left(\text { ha year }^{-1} \text { ) }\right.\end{array}$} & \multirow{2}{*}{$\begin{array}{c}\begin{array}{c}\text { Gross mar- } \\
\text { gin }^{(3)} \\
\text { (ha year }^{-1} \text { ) }\end{array} \\
\text { US\$ } \\
\end{array}$} \\
\hline & & Soy & Corn & Wheat & $\operatorname{Corn}^{(2)}$ & Soy & Corn & Wheat & $\operatorname{Corn}^{(2)}$ & & \\
\hline I & 41,1 & 6 & 6 & 6 & 1 & 3484 & 8006 & 2342 & 4339 & $800.86 \mathrm{a}$ & $1,224.45 \mathrm{a}$ \\
\hline II & 46,0 & 6 & 4 & 5 & 4 & 3398 & 7116 & 2403 & 3549 & $704.85 \mathrm{a}$ & $1,080.89 a$ \\
\hline III & 43,6 & 6 & 4 & 5 & 3 & 2971 & 5282 & 1668 & 1657 & $509.72 \mathrm{~b}$ & $961.41 \mathrm{a}$ \\
\hline IV & 47,8 & 6 & 4 & 5 & - & 2298 & 4893 & 1202 & - & $459.71 \mathrm{~b}$ & $631.68 \mathrm{~b}$ \\
\hline V & 38,7 & 6 & 3 & 6 & - & 2904 & 5605 & 1939 & - & $855.20 \mathrm{a}$ & $590.61 \mathrm{~b}$ \\
\hline VI & 41,1 & 6 & - & - & 6 & 3390 & - & - & 4826 & $802.10 \mathrm{a}$ & $1,244.21 \mathrm{a}$ \\
\hline VII & 53,2 & 6 & - & 3 & 6 & 3099 & - & 3533 & 3815 & $883.30 \mathrm{a}$ & 947.21 a \\
\hline VIII & 28,0 & 6 & - & 6 & - & 3440 & - & 2110 & - & $879.90 \mathrm{a}$ & $920.35 \mathrm{a}$ \\
\hline IX & 26,5 & 6 & - & 6 & - & 3107 & - & 1997 & - & $737.57 \mathrm{a}$ & $913.55 \mathrm{a}$ \\
\hline $\mathrm{X}$ & 9,7 & 3 & 3 & 2 & - & 2308 & 5238 & 2206 & - & $461.56 \mathrm{~b}$ & $536.28 \mathrm{~b}$ \\
\hline XI & 20,6 & 6 & - & 4 & - & 2610 & - & 2171 & - & $711.95 \mathrm{a}$ & $519.30 \mathrm{~b}$ \\
\hline XII & 24,2 & 6 & - & - & 4 & 2624 & - & - & 1850 & $632.91 \mathrm{~b}$ & $443.96 \mathrm{~b}$ \\
\hline XIII & 15,7 & 6 & - & 5 & - & 2396 & - & 2353 & - & $724.61 \mathrm{a}$ & $560.05 \mathrm{~b}$ \\
\hline
\end{tabular}

(1) Farm area used for growing grains. (2) Off-season corn. ${ }^{(3)}$ The mean for the six agricultural years, that is, from 1998/1999 to 2003/2004, is measured in real terms, with July 2016 as the base period. Values followed by the same letter do not differ significantly at the $1 \%$ level, according to the Scott-Knott test. US\$: American Dollars.

Included in the group with the greatest profitability are the following: four NT-MP, one without crop rotation and three with crop rotation, with gross margins of US\$ 961.41 to US\$ 1,244.21 per hectare per year; two NT-ST without crop rotation; and one MPDS-MT without crop rotation, with gross margins of US\$ 913.55 to US\$ 947,21 per hectare per year (Table 3). The relative superiority of NT-MT over NT-ST and MPDS-MT indicates that, over time, the adoption of a no-tillage system is economically profitable. 
The lower profitability group includes one NTMT with crop rotation, one NT-MT with incipient rotation of corn in the summer and a rented planter, three NT-ST without crop rotation and with rented planters and seeders, and one CT-MT without crop rotation and with rented planters and seeders. Despite the lower gross margins of US\$ 443.96 to US\$ 631.68, it can be said that the lower level is economically sustainable. Differences in gross margins are more closely related to the yields obtained, especially in the soybean crop that heads the system. Soybean crop yields in the group with superior profitability ranges between 2,971 and $3,484 \mathrm{~kg} \mathrm{ha}^{-1}$, while in the lower profitability group, where users of rented seeders predominate, yield ranges between 2,308 and 2,904 $\mathrm{kg} \mathrm{ha}^{-1}$. In fact, machine rental is the clearest factor explaining differences in profitability. This factor is more prominent than specialization or production scale, as farms VIII and IX are diversified and operate on a scale that is $60 \%$ that of specialized farms but are positioned in the higher profitability range, whereas farms IV and V, which are specialized and larger scale, are in the lower profitability range. One factor that does not appear to negatively affect profitability or grain yields is occasional scarification, as seen with farms VI (NT-MT without crop rotation) and IX (NT-ST without crop rotation), which are both in the higher gross margin range.

The four largest gross margins were obtained with NT-MT. Of these, three were obtained with crop rotation (US\$ 961.41 to US\$ $1,224.45$ per hectare per year), and one (the highest) was obtained without crop rotation (US\$ 1,244.21 per hectare per year) (Table 3). This result indicates that crop rotation is one of the most efficient practices, although the soybean/off-season corn or soybean/ wheat successions were financially comparable to rotations that included other grains within the period. Two points that should also be kept in mind are, first, that soybean/corn and soybean/wheat successions, because they involve the succession of a legume and a grass, are not exactly monocultures and, second, that the rotations used with corn in the summer and off-season corn, wheat, white oat and triticale in the winter, despite their virtues, would be financially at the same level as relatively simple and successful successions under good management. This result confirms the superiority of systems that involve crop rotation, whether or not they are associated with the use of no-tillage (LAURENTI; FUENTES-LLANILLO, 1981; LEAL et al., 2005; URI, 1999).

Most of these family farms with no-till grain production seek to maximize margins at higher cost (US\$ 704.85 to US\$ 883.30 per hectare per year), while others, such as farms III, IV, X, and XII, adopt a cost minimization strategy (US\$ 459.71 to US\$ 632.91 per hectare per year). Farm III should be highlighted as the only one with lower variable costs and higher gross margins (Table 3 ).

Figure 1 shows the interannual variability in gross margins, along with the annual average gross margin of the two groups and the overall average, in addition to the differences between the first and second triennia. 
Figure 1. Average gross margins of no-tillage grain production systems in family farms.

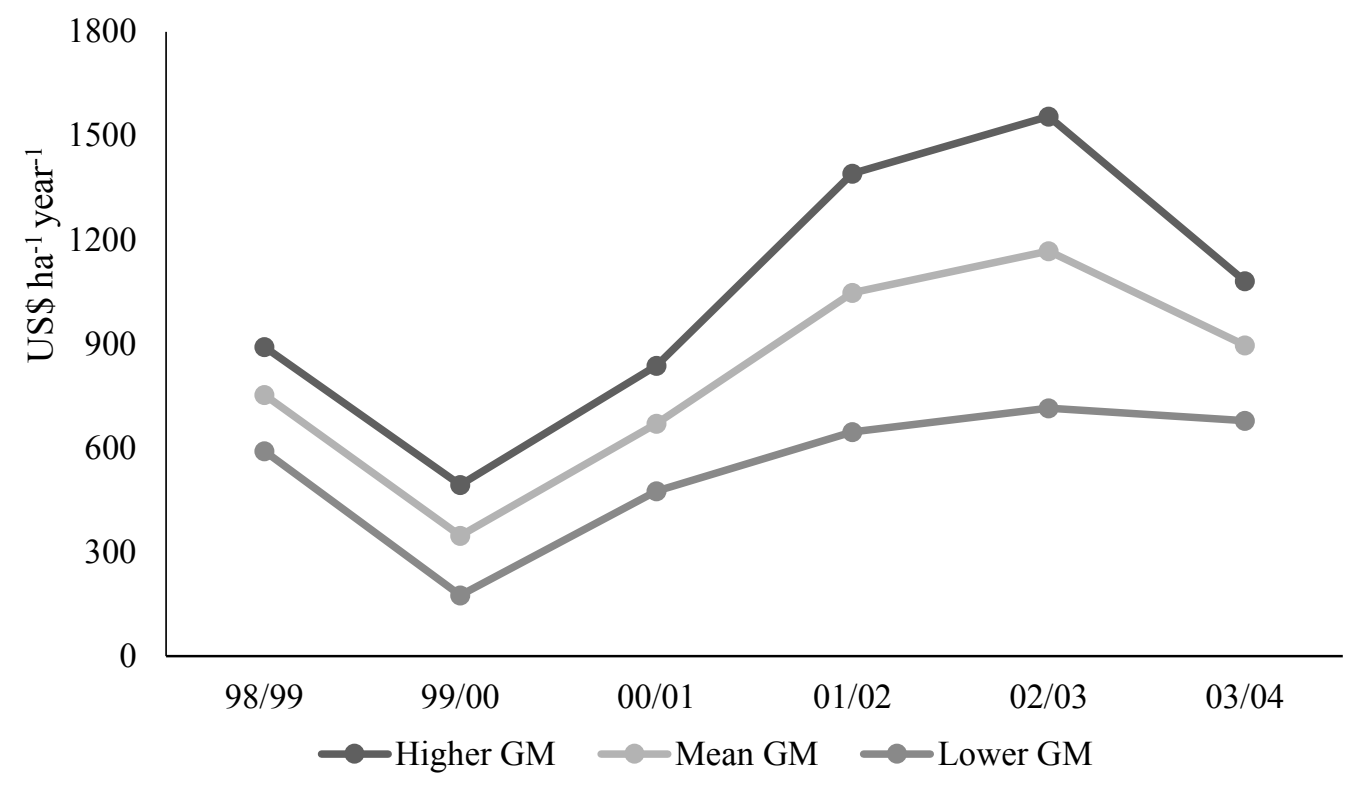

In the most favorable years, due to a combination of climatic and economic factors, the group with the higher gross margins stands out even more prominently from the group with lower gross margins. In the worst years, if, in addition to variable costs, fixed costs and opportunity costs are taken into account, parts of the group with lower gross margins would have no resilience, possibly threatening their economic sustainability.

Some producers have adopted a cost minimization strategy by using fewer inputs or through pest and disease management, biological control practices, and fertilization rationalization. Nevertheless, in current no-tillage, agrochemicals and the number of applications are a significant cost component, limiting gross margins, even in the most economically favorable years, as the input market takes up a portion of the gains in these periods with a short time lag.

The results observed here are consistent with those of Oliveira et al. (2009), in which NTS is found to be a promising way of making the production of grains (corn) technically and economically feasible in family production units in Unaí, Minas Gerais.
According to that study, NTS reduced dependence on rented machinery for soil preparation and lowered the workload involved in weed control. In addition, the yield achieved was above average and allowed for greater valorization of scarce factors such as land and, above all, family labor.

\section{Conclusions}

No-till grain production systems in the north of Paraná are found to be economically profitable, even with crop succession.

Lower grain yields and profitability are associated with the use of rented seeders and planters on smaller-scale plots and to a lack of crop rotation.

In the worst years, profitability is very low, compromising farmer income.

Specialized no-till grain production systems in the north of Paraná are, as a rule, more profitable than those that are diversified.

Diversified producers can obtain similar results, provided they own their planters and seeders or outsource high quality labor. 


\section{Acknowledgements}

The authors thank the farmers who participated in the study for their collaboration; the agricultural technicians from IAPAR, Ronaldo Rossetto and Pedro Machado; the agronomists from EMATERPR, Adenir de Carvalho and Ciro Marcolini; and the researchers from IAPAR, Antônio Carlos Laurenti, Moacyr Doretto, Edson Lima de Oliveira, Wilian Ricce, Paulo Henrique Caramori and Ruy Casão Júnior for the scientific collaboration.

\section{References}

ALMEIDA, W. S.; CARVALHO, D. F.; PANACHUKI, E.; VALIM, W. C.; RODRIGUES, S. A.; VARELLA, C. A. A. Erosão hídrica em diferentes sistemas de cultivo e níveis de cobertura do solo. Pesquisa Agropecuária Brasileira, Brasília, v. 51, n. 9, p. 1110-1119, 2016.

BLAINSKI, É.; TORMENA, C. A.; GUIMARÃES, R. M. L.; NANNI, M. R. Qualidade física de um latossolo sob plantio direto influenciada pela cobertura do solo. Revista Brasileira de Ciência do Solo, Viçosa, MG, v. 36, n. 1, p. 79-87, 2012.

BOLLIGER, A.; MAGID, J.; AMADO, J. C. T.; SKÓRA NETO, F.; RIBEIRO, M. F. S.; CALEGARI, A.; RALISCH, R.; NEERGAARD, A. Taking stock of the Brazilian zero-till revolution: a review of landmark research and farmers' practice. Advances in Agronomy, San Diego, v. 91, p. 47-110, 2006.

CARNEIRO, M. A. C.; SOUZA, E. D.; REIS, E. F.; PEREIRA, H. S.; AZEVEDO, W. R. Atributos físicos, químicos e biológicos de solo de cerrado sob diferentes sistemas de uso e manejo. Revista Brasileira de Ciência do Solo, Viçosa, MG, v. 33, n. 1, p. 147-157, 2009.

CASÃO JÚNIOR, R.; SIQUEIRA, R.; MEHTA, Y. R.; PASSINI, J. J. Sistema plantio direto com qualidade. Londrina: IAPAR; Foz do Iguaçu: ITAIPU Binacional, 2006. $200 \mathrm{p}$.

CASTRO, S. H.; REIS, R. P.; LIMA, A. L. R. Custos de produção da soja cultivada sob sistema de plantio direto: estudo de multicasos no oeste da Bahia. Ciência e Agrotecnologia, Lavras, v. 30, n. 6, p. 1146-1153, 2006.

CAVALETT, O.; ORTEGA, E. Emergy, nutrients balance, and economic assessment of soybean production and industrialization in Brazil. Journal of Cleaner Production, Amsterdã, v. 17, n. 8, p. 762-771, 2009.
CHRISTOFFOLETI, P. J.; CARVALHO, S. J. P.; LÓPEZ-OVEJERO, R. F.; NICOLAI, M.; HIDALGO, E.; SILVA, J. E. Conservation of natural resources in Brazilian agriculture: implications on weed biology and management. Crop Protection, Oxford, v. 26, n. 3, p. 383-389, 2007.

CORTEZ, J. W.; FURLANI, C. E. A.; VIGNA, G. P.; BORSATTO, E. A.; SILVA, R. P. D. Desempenho do trator agricola no manejo da cultura de cobertura e pressão de inflação do pneu da semeadora. Engenharia Agrícola, Jaboticabal, v. 29, n. 1, p. 72-80, 2009.

EL-SHATER, T.; YIGEZU, Y. A.; MUGERA, A.; PIGGIN, C.; HADDAD, A.; KHALIL, Y.; LOSS, S.; AWHASSAN, A. Does zero tillage improve the livelihoods of smallholder cropping farmers? Journal of Agricultural Economics, Chichester, v. 67, n. 1, p. 154-172, 2016.

FERNANDES, H. C.; SILVEIRA, J. C. M.; RINALDI, P. C. N. Avaliação do custo energético de diferentes operações agrícolas mecanizadas. Ciência e Agrotecnologia, Lavras, v. 32, n. 5, p. 1582-1587, 2008.

FUENTES-LLANILLO, R.; TELLES, T. S.; SOARES JÚNIOR, D.; PELLINI, T. Tillage systems on annual crops in Brazil: figures from the 2006 Agricultural Census. Semina: Ciências Agrárias, Londrina, v. 34, n. 6, p. 3691-3698, 2013.

FURLANETO, F. P. D.; ESPERANCINI, M. S. T. Custo de produção e indicadores de rentabilidade da cultura do milho safrinha. Pesquisa Agropecuária Tropical, Goiânia, v. 40, n. 3, p. 297-303, 2010.

HOBBS, P. R.; SAYRE, K.; GUPTA, R. The role of conservation agriculture in sustainable agriculture. Philosophical Transactions of the Royal Society B: Biological Sciences, Londres, v. 363, n. 1491, p. 543$555,2008$.

KASSAM, A.; FRIEDRICH, T.; SHAXSON, F.; PRETTY, J. The spread of conservation agriculture: justification, sustainability and uptake. International Journal of Agricultural Sustainability, Abingdon, v. 7, n. 4, p. 292-320, 2009.

KHATOUNIAN, C. A.; SOARES JÚNIOR, D. Abordagem sistêmica e pesquisa participava na agricultura familiar: ferramentas para o desenvolvimento. Informe Agropecuário, Belo Horizonte, v. 26, p. 17-27, 2005. Edição Especial.

LAL, R. Evolution of the plow over 10,000 years and the rationale for no-till farming. Soil and Tillage Research, Amsterdã, v. 93, n. 1, p. 1-12, 2007. 
LAURENTI, A. C.; FUENTES-LLANILLO, R. Avaliação de custos, rentabilidade e risco. In: Fundação Instituto Agronômico do Paraná. (Org.). Plantio direto no Estado do Paraná. Londrina: IAPAR, 1981. p. 215237. (Circular IAPAR, 23)

LEAL, A. J. F.; LAZARINI, E.; TARSITANO, M. A. A.; SÁ, M. E.; GOMES JÚNIOR, F. G. Viabilidade econômica da rotação de culturas e adubos verdes antecedendo o cultivo de milho em sistema de plantio direto em solo de cerrado. Revista Brasileira de Milho e Sorgo, Sete Lagoas, v. 4, n. 3, p. 298-307, 2005.

LIBARDI, D.; DELGADO, P. A redução do trabalho agrícola no Paraná. Revista Paranaense de Desenvolvimento, Curitiba, n. 95, p. 51-59, 1999.

MENDES, I. C.; TOURDONNET, S. Conservation agriculture cropping systems in temperate and tropical conditions and tropical conditions, performances and impacts. A review. Agronomy for Sustainable Development, Paris, v. 33, n. 1, p. 113-130, 2013.

MIRANDA, M.; CARNEIRO, S. L.; SOARES JÚNIOR, D.; FUENTES-LLANILLO, R. Enfoque sistêmico e redes de referências para agricultura familiar. Informe Agropecuário, Belo Horizonte, v. 30, n. 250, p. 22-28, 2009.

OLIVEIRA, C. M.; SANTANA, A. C.; HOMMA, A. K. O. Os custos de produção e a rentabilidade da soja nos municípios de Santarém e Belterra, estado do Pará. Acta Amazonica, Manaus, v. 43, n. 1, p. 23-32, 2013.

OLIVEIRA, J. G. R.; RALISCH, R.; GUIMARÃES, M. F.; BARBOSA, G. M. C.; TAVARES FILHO, J. Erosão no plantio direto: perda de solo, água e nutrientes. Boletim de Geografia, Maringá, v. 30, n. 3, p. 91-98, 2012.

OLIVEIRA, M. N.; XAVIER, J. H. V.; SILVA, F. A. M.; SCOPEL, E.; ZOBY, J. L. F. Efeitos da introdução do sistema de plantio direto de milho por agricultores familiares do município de Unaí, MG (Cerrado Brasileiro). Pesquisa Agropecuária Tropical, Goiânia, v. 39, n. 1, p. 51-60, 2009.

ROSIM, D. C.; MARIA, I. C. de; SILVA, R. L.; SILVA, A. P. Compactação de um Latossolo Vermelho Distroférrico com diferentes quantidades e manejos de palha em superfície. Bragantia, Campinas, v. 71, n. 4, p. 502-508, 2012.

SÁ, J. C. M.; LAL, R. Stratification ratio of soil organic matter pools as an indicator of carbon sequestration in a tillage chronosequence on a Brazilian Oxisol. Soil and Tillage Research, Amsterdã, v. 103, n. 1, p. 46-56, 2009.
SABUNDJIAN, M. T.; ARF, O.; TARSITANO, M. A. A.; KANEKO, F. H.; CORSINI, D. C. D. C. Análise econômica da adubação nitrogenada em feijoeiro de inverno sob plantio direto. Pesquisa Agropecuária Tropical, Goiânia, v. 44, n. 4, p. 349-356, 2014.

SANTOS, H. G.; JACOMINE, P. K. T.; ANJOS, L. H. C.; OLIVEIRA, V. A.; OLIVEIRA, J. B.; COELHO, M. R.; LUMBRERAS, J. F.; CUNHA, T. J. F. (Ed.). Sistema brasileiro de classificação de solos. 2. ed. Rio de Janeiro: Embrapa Solos, 2006. 306 p.

SAPKOTA, T. B.; MAZZONCINI, M.; BÀRBERI, P.; ANTICHI, D.; SILVESTRI, N. Fifteen years of no till increase soil organic matter, microbial biomass and arthropod diversity in cover crop-based arable cropping systems. Agronomy for Sustainable Development, Paris, v. 32, n. 4, p. 853-863, 2012.

SCOPEL, E.; TRIOMPHE, B.; AFFHOLDER, F.; SILVA, F. A. M.; CORBEELS, M.; XAVIER, J. H. V.; LAHMAR, R.; RECOUS, S.; BERNOUX, M.; BLANCHART, E.; MENDES, I. C.; TOURDONNET, S. Conservation agriculture cropping systems in temperate and tropical conditions and tropical conditions, performances and impacts. A review. Agronomy for Sustainable Development, Paris, v. 33, n. 1, p. 113-130, 2013.

SILVA, A. A.; GALON, L.; FERREIRA, F. A.; TIRONI, S. P.; FERREIRA, E. A.; SILVA, A. F.; ASPIAZÚ, I.; AGNES, E. L. Sistema de Plantio Direto na Palhada e seu impacto na agricultura brasileira. Revista Ceres, Viçosa, MG, v. 56, n. 4, p. 496-506, 2009.

SILVA, M. B.; KLIEMANN, H. J.; SILVEIRA, P. M.; LANNA, A. C. Atributos biológicos do solo sob influência da cobertura vegetal e do sistema de manejo. Pesquisa Agropecuária Brasileira, Brasília, v. 42, n. 12, p. 1756-1761, 2007.

URI, N. D. The economic benefits and costs of conservation tillage. Journal of Sustainable Agriculture, Binghamton, v. 15, n. 1, p. 5-27, 1999.

WINCK, B. R.; VEZZANI, F. M.; DIECKOW, J.; FAVARETTO, N.; MOLIN, R. Carbono e nitrogênio nas frações granulométricas da matéria orgânica do solo, em sistemas de culturas sob plantio direto. Revista Brasileira de Ciência do Solo, Viçosa, MG, v. 38, n. 3, p. 980-989, 2014. 